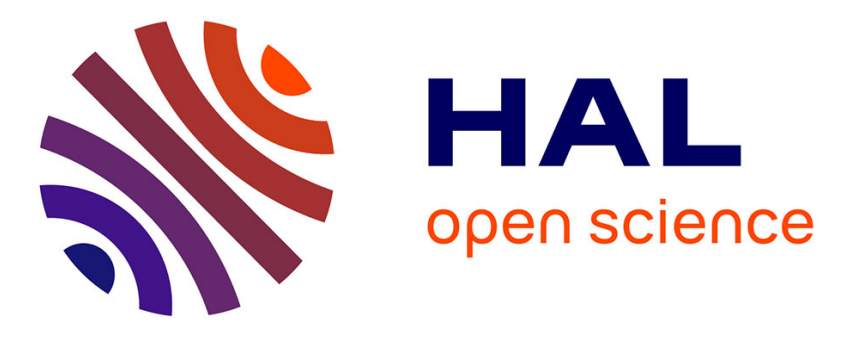

\title{
Corporate Social Responsibility in Social Media Environment
}

\author{
Antonín Pavlíček, Petr Doucek
}

\section{To cite this version:}

Antonín Pavlíček, Petr Doucek. Corporate Social Responsibility in Social Media Environment. 3rd International Conference on Information and Communication Technology-EurAsia (ICT-EURASIA) and 9th International Conference on Research and Practical Issues of Enterprise Information Systems (CONFENIS), Oct 2015, Daejon, South Korea. pp.323-332, 10.1007/978-3-319-24315-3_33 . hal01466233

\section{HAL Id: hal-01466233 \\ https://hal.inria.fr/hal-01466233}

Submitted on 13 Feb 2017

HAL is a multi-disciplinary open access archive for the deposit and dissemination of scientific research documents, whether they are published or not. The documents may come from teaching and research institutions in France or abroad, or from public or private research centers.
L'archive ouverte pluridisciplinaire HAL, est destinée au dépôt et à la diffusion de documents scientifiques de niveau recherche, publiés ou non, émanant des établissements d'enseignement et de recherche français ou étrangers, des laboratoires publics ou privés.

\section{(c)(1)}

Distributed under a Creative Commons Attribution| 4.0 International License 


\title{
Corporate Social Responsibility in Social Media environment
}

\author{
Antonín Pavlíček ${ }^{1}$, Petr Doucek ${ }^{1}$ \\ ${ }^{1}$ University of Economics, Prague, W. Churchill sq. 3 \\ 13067 Prague, Czech Republic \\ \{antonin.pavlicek, doucek\}@vse.cz
}

\begin{abstract}
The paper describes corporate social responsibility (CSR) communication on Facebook and Twitter - how the companies use the social media for accomplishing their CSR communication goals. On the sample of ten global companies with the best CSR reputation research tracks down their social media activity, as well as posts, likes and comments of their customers. Observed companies on average dedicate about $1 / 10$ of their social media communication bandwidth to CSR topics, mainly on Facebook. CSR topics do not seem to be of much interest to the readers (CSR posts are mostly ignored), but at least user sentiment related to CSR messages has been proven to be mostly positive. CSR on social networks is well established, leading CSR companies use this communication channel extensively
\end{abstract}

Keywords: Corporate social responsibility, CSR, Facebook, Twitter, good practice, social media

\section{Introduction}

The article deals with corporate social responsibility (from now on "CSR") activities published on Facebook and Twitter. We have analyzed ten multinational companies that ranked in the world's 100 most CSR reputable companies in Forbes [1].

\subsection{Corporate Social Responsibility}

Corporate social responsibility is capturing an idea of responsible companies respecting the concept of people, planet, and profit ${ }^{1}$. First debates about CSR published in 1930's Harward Law Review. Professors Adolf A. Berle [2] and Merrick Dodd [3] asked: Do the managers have responsibility only for their firm or do they have a wider range of responsibilities?

Today world has started to care about global and local issues with social and environmental aspects "Corporate Social Responsibility is a way of doing business that matches or exceeds ethical, legal, commercial and social expectations." [4] Some-

${ }^{1}$ People, planet, profit are also called three pillars of sustainability or triple bottom line 
times CSR is called sustainable, responsible business, corporate citizenship, etc. CRS is may be still perceived as something like a charity or donation pleading, but donations and similar activities are only a part of it. CSR cover topic like transparency and responsible attitude in everyday work and decision-making. Current trends in CSR are water and energy wasting, carbon printing, transparency, traceability, human rights, and labor standards.

We can divide the motivation for CSR into four main areas of benefits. First business benefits. They are connected with gaining money, power, market share, etc. Next benefits are about individual / personal values. The company is trying to be seen in a better light. It's connected with branding since the reputation of the company is getting more and more important in business relationships. A third group of benefits is about complying with industry's social and legislative expectations. And of course we can't forget stakeholders - the company has to fulfill their expectations as well. These expectations can be diverse since stakeholders are varied. For example, the expectations of employees are reliability, future development, sustainability, the transparent benefits system, HR care, outplacement, etc. Crucial stakeholders became business partners, especially European companies require trading with companies proving they're caring about environment and society. To identify benefits, which company wants to gain is paramount for further setting CRS activities.

From theoretical concept, CSR has evolved to a sophisticated managing tool used not only to build company's reputation, but also to enlarge its competitive advantage.

Until recently, CSR in the company was mainly about overtimes and sexual harassment, shortly it was about keeping the company out of the trouble. Now the companies are implementing CSR in more far-reaching ways. There are four recognized stages of CSR in enterprise - see Figure 1.

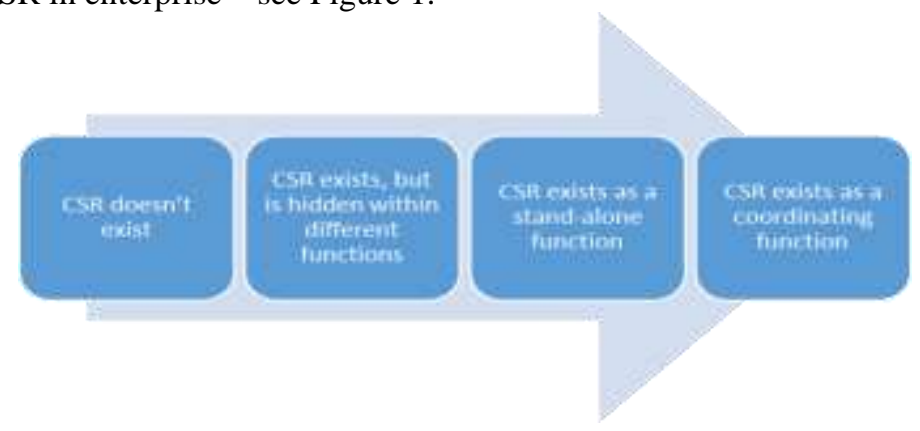

Fig. 1. Four Stages of CSR in Enterprise

Just a few companies are in the stage one. A lot of activities, companies are actually doing, even unknowingly, are CSR. For example benefits for employees or HR policies. The goal for every CSR oriented company is to reach enterprise CSR maturity. It includes changes in company values and business thinking, as well as official standards. Employees should share CSR values too. Without integrating employees into the process, CRS strategy fails. 


\subsection{CSR in the Czech Republic}

After 1990 companies usually focused just on one goal - the maximization of financial profit. Later some firms realized that it is quite important to look towards the further future and consider public gains as well. CRS has very deep roots in the Czech Republic - the first businessman involved in CSR activities was Tomáš Bata (founder of Bata shoemaking company). Long time before official term CSR was used he realized, that if he wanted to make high-quality shoes, he has to have satisfied employees. The logical conclusion of dissatisfied and stressed employees are mistakes and nonfunctional plant. Tomáš Bata became a role model for other businessmen not only in his days. [5] Czech Republic understands corporate social responsibility the same way as EU does. The European Commission defined CSR as "the responsibility of enterprises for their impacts on society".

CSR activities are also closely related to another important topic - quality. Czech Ministry of Industry and Trade adopted programs that should help companies improve quality and also cultivate market environment. The government nominated The Council of Quality as an advisory authority on CSR. One of the programs adopted by Council of Quality is "National Quality Policy of the Czech Republic for CSR activities". The primary aim of this program is to make CSR activities popular and award the most social responsible companies.

\section{Social Media}

There are many definitions of social media - it is possible to define social media from the user, content, business or technological perspective [7]. Figure 2 shows such triangle of content, technological and sociological aspect of social media. Andreas Kaplan and Michael Haenlein in their paper define social media as ,a group of internet-based applications that build on the ideological and technological foundations of Web 2.0, and allow the creation and exchange of user-generated content." [8] In other words, Kaplan and Haenlein build their definition on technological aspect.

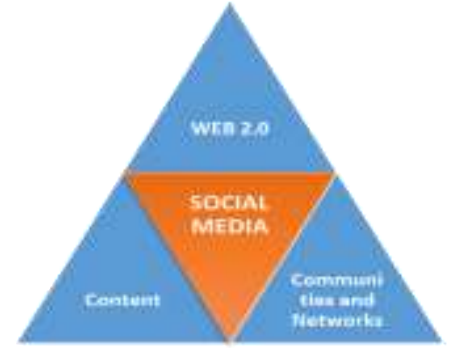

Fig. 2. Three key elements of social media [9]

We can also break the term social media into two words - social and media in order to describe and understand meaning of the whole. Social can be described as a group of people with relations between them while media can be described as an instrument with the purpose to provide communication. By putting these two words 
together, we get, that social media is an instrument of on-line communication between people (users of social media). These people can create information, share and exchange them with other users in specific places such as networks or in general virtual communities. Social media affects our everyday personal or business life in both positive and negative way.

\section{Negative effects of social media}

The most discussed issue with social media is a trustworthiness and reliability of information that they provide. Social media websites or posts in social networks are, in general, easy to create, and can contain (knowingly or accidentally) a lot of false statements and information that can confuse other users.

People can even become ,addicted" to social media by spending a too much time online and lose their personal life. Loss of privacy is another critical issue of social media.[10][11]

There is also possible thread on user's computer security. Many social media can be intoxicated with security risks (viruses such malware of spyware etc.) or bugs that allow criminals to access victims' computer or even bank accounts and steal (or delete) information or finances.

\section{Positive effects of social media}

The existence of social media allows the democratization of the internet. Users can share what they want, express their feelings and opinions on topics or for example vote in online polls. Information flows have been relaxed and enriched by them.

As the biggest advantage of social media is considered the fact, that people can stay in touch with friends, families and also connect with other users and make new friends or form relationships. Social media is also used for learning and gaining new skills and knowledge. By using social media, people can reach a wider audience in comparison with traditional media and they can also, individually or in collaboration, create new content and manage it. Social media can be used in education too. Knowledge bases like Wikipedia contain a lot of information and can help users to understand what they are looking for or help solve problems.

Social media is very powerful tool in business too. It helps to expand the markets, or promote a brand to a wide audience or improve the relationship with customers among many other things. These days, marketing in business is one of the most important things for a company to stay competitive. There is no better place where to make good marketing strategies than social media. [12] [9]

\section{Research Questions}

Our goal is to understand how the successful and worldwide famous companies are using social media for their CSR activities promotion and communication with customers and the general public. We have formulated following research questions:

- How do successful companies use the social media to spread CSR news?

- How do users of social networks respond CSR news? Does a reaction to CSR messages differ in comparison with other non-CSR messages? 
We will closely look at the interaction of the general public and the companies - by analyzing the posts structure /Commercials, HR News, CSR/ and focusing on the interaction with the audience.

\section{$4 \quad$ Research Methodology}

We decided to research corporate social responsibility activities on the two prominent social sites - Facebook and Twitter. The period of observation was three months (September - November 2014), during which we recorded all the posts of the selected companies.

The selection of the companies was based on Forbes' article The Companies with the Best CSR Reputations.[1] It covers 50.000 consumers' opinions about the list of 100 most reputable companies. We have focused on the top 10 of the list: Volkswagen, Sony, Colgate-Palmolive, Lego Group, BMW, Mercedes-Benz (Daimler), Apple, Google Inc., Microsoft Corporation and Walt Disney. All the companies have the official Facebook and Twitter profile except Apple. Therefore, we had to replace Apple by another major ICT company - SAP Corporation.

Our main goal was to track CSR activity of each company across the social media. We observed and analyzed all and every post of selected companies both on Facebook and Twitter. Then, based on meaning of the posts, we categorized these social media posts into following categories:

- non-CSR messages (advertisements/commercials, staff hiring, new technology announcements)

- CSR activity.

We noted the number of "likes" each post received and also positive and negative feedback in the comments.

\section{$5 \quad$ Results}

The results may be affected by the time-constraints since we only tracked social media activity for three months. Nevertheless, we have collected and analyzed in total:

- 466 posts of the observed companies (in the structure of 375 advertisements, 26 new technologies announcements, 4 HR announcements and 60 CSR announcements)

- $1,407,108$ likes of above-mentioned posts

- 139,421 shares of above-mentioned posts

- 13,816 feedbacks (both positive and negative) to above-mentioned posts.

General result is, that CSR activity on social media highly varies among all observed companies. Fewer CSR messages are published on Twitter (just $26 \%$, as opposed to almost $44 \%$ of advertisements). For CSR messages, companies like to use 
advantages of Facebook with its billion+ users. To show some examples of typical CSR Facebook activity, there are some typical Facebook CSR posts:

- Man with Down syndrome empowers others using technology (14/11/2014) - Microsoft

- Introducing Microsoft Health (30/10/2014) - Microsoft

- From 1st till 10th August the Think Blue (2/8/2014) - Volkswagen

- ALS Ice Bucket Challenge (27/8/2014) - Colgate-Palmolive

- Fight Ebola (10/11/2014) - Google

- Hyper build (14/9/2014) - Lego

- The Autism Society Philippines (20/11/2014) - SAP

- Event: St. Moritz Art Masters 2014 - Mercedes-Benz (Daimler)

From the collected data is quite clear, that companies primarily $(80.47 \%)$ advertise their goods and products -375 out of 466 posts were categorized as Advertisements. CSR messages, on the other hand, accounted for $12.88 \%$ of posts, which makes them the second biggest category.

Table 1. Structure of the social media posts (authors)

\begin{tabular}{lrrrrr}
\hline & $\begin{array}{c}\text { Total number } \\
\text { of posts }\end{array}$ & $\begin{array}{c}\text { Advertise- } \\
\text { ments }\end{array}$ & $\begin{array}{c}\text { New Techno- } \\
\text { logies }\end{array}$ & Staff Hiring & $\begin{array}{c}\text { CSR } \\
\text { messages }\end{array}$ \\
\hline Colgate & $\mathbf{5}$ & 2 & 0 & 0 & 3 \\
Lego & $\mathbf{1 8}$ & 12 & 1 & 0 & 5 \\
SAP & $\mathbf{4 4}$ & 15 & 4 & 1 & 24 \\
Sony & $\mathbf{4 5}$ & 41 & 2 & 0 & 2 \\
Volkswagen & $\mathbf{4 7}$ & 39 & 5 & 0 & 2 \\
Google & $\mathbf{4 8}$ & 43 & 1 & 0 & 4 \\
Walt Disney & $\mathbf{5 0}$ & 50 & 0 & 0 & 0 \\
Microsoft & $\mathbf{5 6}$ & 43 & 8 & 0 & 5 \\
BMW & $\mathbf{6 3}$ & 62 & 1 & 0 & 0 \\
Daimler & $\mathbf{9 0}$ & 68 & 4 & 3 & 15 \\
Total & $\mathbf{4 6 6}$ & $\mathbf{3 7 5}$ & $\mathbf{2 6}$ & $\mathbf{4}$ & $\mathbf{6 0}$ \\
& $100 \%$ & $80.47 \%$ & $5.58 \%$ & $0.86 \%$ & $12.88 \%$ \\
\hline Facebook & $268(58 \%)$ & $208(56 \%)$ & $15(58 \%)$ & $1(25 \%)$ & $44(74 \%)$ \\
Twitter & $198(42 \%)$ & $167(44 \%)$ & $11(42 \%)$ & $3(75 \%)$ & $16(26 \%)$ \\
\hline
\end{tabular}

As for feedback, it can be measured in three different ways. The first and most obvious one is the number of "likes", which are awarded by readers to all posts. Table with the numbers of received likes by the companies in different categories follows.

Table 2. Total number of "likes" for different categories of posts (authors)

\begin{tabular}{lrrrrr}
\hline Fans & $\begin{array}{c}\text { Advertise- } \\
\text { ments } \\
\text { „likes“ }\end{array}$ & $\begin{array}{c}\text { New Techno- } \\
\text { logies } \\
\text { „likes“ }\end{array}$ & $\begin{array}{c}\text { Staff Hiring } \\
\text { „likes“ }\end{array}$ & $\begin{array}{c}\text { CSR } \\
\text { messages } \\
\text { „likes“ }\end{array}$ \\
\hline Colgate & $2,800,000$ & 2,599 & N/A & N/A & 593
\end{tabular}




\begin{tabular}{lrrrrr} 
Lego & $10,200,000$ & 122,076 & N/A & N/A & 2,789 \\
SAP & 590,000 & 777 & 109 & 48 & 284 \\
Sony & $6,800,000$ & 127,354 & 10,426 & N/A & 10,867 \\
Volkswagen & $1,600,000$ & 45,201 & 8,391 & N/A & 1,450 \\
Google & $18,400,000$ & 21,641 & 135 & N/A & 1625 \\
Walt Disney & 860,000 & 59,468 & N/A & N/A & N/A \\
Microsoft & $6,500,000$ & 83,388 & 1,976 & N/A & 3,003 \\
BMW & $18,300,000$ & 416,586 & N/A & N/A & N/A \\
Daimler & $18,250,000$ & 477,186 & 134 & 68 & 8,934 \\
Total & $\mathbf{8 4 , 3 0 0 , 0 0 0}$ & $\mathbf{1 , 3 5 6 , 2 7 6}$ & $\mathbf{2 1 , 1 7 1}$ & $\mathbf{1 1 6}$ & $\mathbf{2 9 , 5 4 5}$ \\
\hline
\end{tabular}

The second way how to measure feedback is number of "shares" 2 - i.e. how many times the users "pass on" the recommendation for posts. Again, here are the numbers:

Table 3. Total number of "shares" for different categories of posts (authors)

\begin{tabular}{lrrrr}
\hline & $\begin{array}{c}\text { Advertise- } \\
\text { ments } \\
\text { shares“ }\end{array}$ & $\begin{array}{c}\text { New Techno- } \\
\text { logies } \\
\text { „shares“ }\end{array}$ & $\begin{array}{c}\text { Staff Hiring } \\
\text { „shares“ }\end{array}$ & $\begin{array}{c}\text { CSR } \\
\text { messages } \\
\text {,shares“ }\end{array}$ \\
\hline Colgate & 119 & N/A & N/A & 85 \\
Lego & 11,351 & N/A & N/A & 274 \\
SAP & 68 & 8 & 1 & 32 \\
Sony & 4,812 & 437 & N/A & 620 \\
Volkswagen & 2,318 & 871 & N/A & 134 \\
Google & 12,551 & 169 & N/A & 379 \\
Walt Disney & 21,163 & & N/A & N/A \\
Microsoft & 20,880 & 541 & N/A & 590 \\
BMW & 21,001 & N/A & N/A & N/A \\
Daimler & 39,806 & 78 & 46 & 1,087 \\
Total & $\mathbf{1 3 4 , 0 6 9}$ & $\mathbf{2 , 1 0 4}$ & $\mathbf{4 7}$ & $\mathbf{3 , 2 0 1}$ \\
\hline
\end{tabular}

Lastly, we have also measured the feedback, provided by the users. After careful individual analysis of the content of their comments, we have divided the reactions to positive and negative feedback - both for CSR and non-CSR posts. The results are following:

Table 4. Positive and negative feedback for CSR and non-CSR posts (authors)

\begin{tabular}{lrrrrrr}
\hline & \multicolumn{3}{c}{ Non-CSR posts } & \multicolumn{3}{c}{ CSR posts } \\
& $\begin{array}{c}\text { Positive } \\
\text { feedback }\end{array}$ & $\begin{array}{c}\text { Negative } \\
\text { feedback }\end{array}$ & $\begin{array}{c}\text { Positive/ } \\
\text { Negative } \\
\text { ratio }\end{array}$ & $\begin{array}{c}\text { Positive } \\
\text { feedback }\end{array}$ & $\begin{array}{c}\text { Negative } \\
\text { feedback }\end{array}$ & $\begin{array}{c}\text { Positive / } \\
\text { Negative } \\
\text { ratio }\end{array}$ \\
\hline Colgate & 28 & 35 & 0.8 & 5 & 3 & 1.67
\end{tabular}

2 There is a difference between "like" and "share" on Facebook. "Like" just means that user finds something interesting, "Share" actually distributes the message to other users. 


\begin{tabular}{lrrrrrr} 
Lego & 600 & 221 & 2.71 & 16 & 5 & 3.2 \\
SAP & 9 & 2 & 4.5 & 0 & 0 & \\
Sony & 479 & 119 & 4.03 & 86 & 2 & 43 \\
Volkswagen & 357 & 190 & 1.88 & 16 & 4 & 4 \\
Google & 6,439 & 1024 & 6.29 & 50 & 1 & 50 \\
Walt Disney & 364 & 177 & 2.06 & 0 & 0 & \\
Microsoft & 967 & 827 & 1.17 & 215 & 6 & 35.83 \\
BMW & 235 & 57 & 4.12 & 1 & 1 & 1 \\
Daimler & 1,256 & 10 & 125.6 & 10 & 1 & 10 \\
Total & $\mathbf{1 0 , 7 3 4}$ & $\mathbf{2 , 6 6 2}$ & $\mathbf{4 . 0 3}$ & $\mathbf{3 9 9}$ & $\mathbf{2 3}$ & $\mathbf{1 7 . 3 5}$ \\
\hline
\end{tabular}

\section{$6 \quad$ Findings and Interpretation}

Observed companies had in total almost 85 million strong audience on Facebook and 27.5 million followers on Twitter. It is really large amount of potential customers that companies definitively can't ignore. Over $80 \%$ of the Facebook and Twitter posts were advertisements directly targeted to drive costumers' attention to new advertised goods or services. However, the second most frequent (almost $13 \%$ ) type of communication were CSR messages.

The prevalence of CSR messages was different on Facebook and Twitter. Companies have shared $3 / 4$ of all CSR communication on Facebook, leaving just $1 / 4$ for Twitter channel, although general ratio of Facebook / Twitter communication in the observed period was almost half to half. It means that companies prefer Facebook as their main channel for CSR announcements. There were no exemptions from this rule observed during our study.

As for audience appreciation (measured by Facebook likes) - it turns out, that CSR messages are surprisingly "unpopular". Although the CSR messages accounted for $13 \%$ of the traffic, they generated only slightly over $2 \%$ of total "likes". The average number of likes per commercial post was 3064, the average number of likes per CSRrelated post was 903 . Worse "underperformer" was only category of HR related messages, which was ignored by users almost completely. The relation of re-tweeting of CSR message was also significantly lower than expected, as opposed to Technological news category tweets, which - on the other hand - were re-distributed enthusiastically through Twitter environment.

The same picture is seen when we analyze the content "shared" 3 on Facebook. Again, the majority of shared content - almost $98 \%$ - was related to products, services or new technologies, leaving CSR messages with just 2,3\% share.

The only good results scored by CSR communication was positive "sentiment" of the feedback. When analyzed on positive/negative scale, the user comments related to CSR activities were four times more positive than the rest. Positive/Negative ratio of the Non-CSR post was in average 4.03 - which means four positive comments to each

${ }^{3}$ There is a difference between "like" and "share" on Facebook. "Like" means that user finds something interesting, "Share" actually distributes the message to other designated users. 
negative one; CSR-related posts achieved on average over 17 positive remarks to one negative.

Our findings prove that advertisements (commercial news) are way ahead of CSR activity on Social Networks. Almost all companies have more commercial focused Facebook and Twitter posts then CSR related posts. For example, Google has 43 commercial posts and only 4 about CSR. It is a similar situation with Volkswagen. They have 39 commercial posts yet only 2 dedicated to CSR. The only exception is company SAP, which has twice as much CSR posts in comparison with commercials.

Based on our research, we found out that most of the observed companies include CRS in their communication strategy. Almost all of observed companies use social media to advertise new product or strategies.

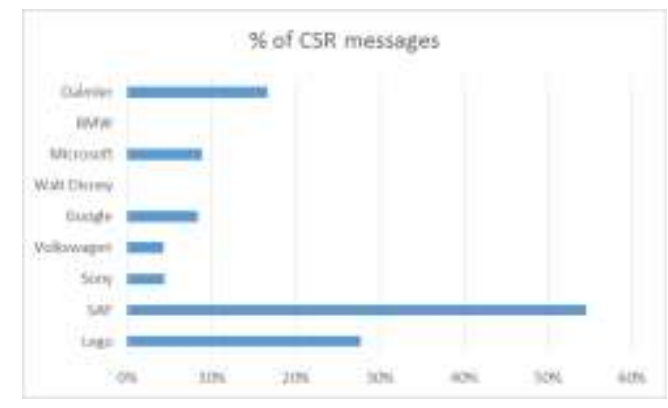

Fig. 3. Comparison of companies by the percentage of CSR posts (out of all posts)

Companies SAP and Lego belong to the most active from the perspective of CSR posts, on the other hand, The Walt Disney Company and BMW do not publish their CSR activity on social networks at all.

\section{Conclusions}

Our study showed that worldwide leaders in the field of CSR do not underestimate their CSR activity on social networks, and they actively promote there. The rate of CSR-related communication varies, but in average amounts to $13 \%$ and CSR is the second most frequent subject on social media.

Slightly worse is the reaction of the audience to CSR-related posts and tweets. CSR-related communications received on average only one-third of "likes" compared with other posts, and people do not tend to pass on the message- "viral effect" of CSR is just $2 \%$. Still, when the CSR-related messages do get some response, then the comments are exceptionally positive.

The conclusion is clear - CSR on social networks is well established, leading CSR companies use this communication channel extensively. A similar trend can be expected in the future also from other firms, which CSR do not follow yet.

Acknowledgments. The research for this paper was conducted with help of students from the course 4SA526 New Media at University of Economics, Prague. 


\section{$8 \quad$ References}

1. Dill, K., "The Companies With The Best CSR Reputations," Forbes, New York (2014)

2. Berle, A. A. "Corporate powers as powers in trust," Harward Law Review., no. 44, pp. 1049 - 1074, (1931)

3. Dodd E. M., "For whom are corporate managers trustees.," Harward Law Review., no. 44, pp. $1145-1163,(1932)$

4. Sigmund T., "Ethics in the Cyberspace," In: IDIMT-2013 Information Technology Human Values, Innovation and Economy. ISBN 978-3-99033-083-8. vol. 42, pp. 269-279, Trauner Verlag, Linz (2013)

5. Briš, P., Svoboda J., Brišová H. “The Growing Importance of the Practical Application of Corporate Social Responsibility in the Management of Companies in the Czech Republic" Journal of Competitiveness., vol. 5, no. 2, pp. 124-138 DOI: 10.7441/joc.2013 .02.09 (2013)

6. Hykš O., Plášková A., "The Czech National CSR Award Model” In: VIII. International Science Conference. pp. 1636-1638 WASET, Zurich (2014)

7. Skrabalek J., Kunc, P., Nguyen F., Pitner, T. "Towards Effective Social Network System Implementation," New Trends in Databases and Information Systems In: Advances in Intelligent Systems and Computing vol. 185, pp. 327-336, DOI 10.1007/978-3-64232518-2_31 (2013)

8. Doucek, P., Pavlicek, A., Nedomova, L. “Information Management in Web 2.0 Technology Context - Changes in Competitiveness Requirements on ICT graduates," Strategic Management ITS Support by Inf. Syst., pp. 34-45 (2011).

9. Ahlqvist, T. Social media roadmaps: exploring the futures triggered by social media, VTT (2008)

10. Boehmova L, Malinova, L. "Facebook User's Privacy in Recruitment Process" In: IDIMT2013 Information Technology Human Values, Innovation and Economy. ISBN 978-399033-083-8. vol. 42, pp. 159-166, Trauner Verlag, Linz (2013)

11. Sigmund, T. "Privacy In The Information Society: How To Deal With Its Ambiguity?" In: IDIMT-2014 Networking Societies - Cooperation and Conflict.. ISBN 978-3-99033-3402, vol. 43, pp. 191-204, Linz: Trauner (2014)

12. Smutny, Z., Reznicek, V. Pavlicek, A. "Measuring the Effects of Using Social Media In: IDIMT-2013 Information Technology Human Values, Innovation and Economy. ISBN 978-3-99033-083-8. vol. 42, pp. 175-178, Trauner Verlag, Linz (2013) 